\title{
LOGICAL POSITIVISM AND ISLAMIC ECONOMICS
}

\author{
Asad Zaman \\ Vice Chancellor, Pakistan Institute of Development Economics, $Q A U$ \\ Campus, Islamabad (Email: asadzaman@alum.mit.edu)
}

\begin{abstract}
This paper provides a detailed discussion of current methodology of economics and its emergence from secular roots in Europe. The foundational principles of this methodology, which is based on logical positivism, are in conflict with Islam. We then sketch some alternative methodologies, which would be more suitable for Islamic economics. We first describe how logical positivism emerged as the dominant philosophy of science, and how it was adopted into the foundations of economics. We then show that the current economic methodology is based on logical positivism. This philosophy is anti-Islamic, and therefore cannot be used to construct Islamic Economics. There are two main points of opposition. Logical Positivism rejects the unseen, while Islam requires faith in the unseen. Logical Positivism rejects morality as unscientific, while morality is a central part of Islamic teachings. This means that a methodology for Islamic economics must be radically different from that currently in use in conventional economic theory. Some essential elements of an alternative methodology are sketched.
\end{abstract}

JEL Classification: B41, B59

Keywords: Logical Positivism, Methodology, Islamic Economics

\section{HISTORICAL BACKGROUND OF LOGICAL POSITIVISM}

Our first goal is to show that current methodology of economics is based on the failed philosophy of logical positivism. To understand the philosophy of logical positivism, it is necessary to discuss the historical background and context of the emergence of this philosophy within European history. It is only in context of this history that the emergence of this philosophy and why it took the 
shape that it did, can be understood. The goal of this first section is to provide the necessary historical background.

\subsection{THE FAILURES OF CHRISTIANITY}

Between the sixteenth and the eighteenth century, there was a dramatic change in European ways of thinking from Christianity based to secular. This transition has been documented in many different books on the subject. For example, Tawney (1926) writes that "The theory of a hierarchy of values, embracing all human interests and activities in a system of which the apex is religion, is replaced by the conception of separate and parallel compartments, between which a due balance should be maintained, but which have no vital connection with each other." A key ingredient of secular thought is the idea that there are domains of human activity (economic, political, etc.) which are outside the scope of religion. This idea is unacceptable in terms of the central teachings of both Islam and Christianity. It was only the removal of Christianity from the public sphere that made this development possible. Why did Europeans abandon Christianity as a whole, and supplant it by secular thought? There are many reasons for this:

1. Christianity was too idealistic, and set up goals which were virtually impossible for normal human beings. For example, the state of poverty and celibacy were idealized, while marriage and wealth were considered as concessions to human weaknesses. The contrast with Islam is obvious.

2. Extremely corrupt behavior of a sequence of Popes in the sixteenth century has been called "the most consequential (event) in western history, if measured by its result in centuries of ensuing hostility and fratricidal war" by Tuchman (1985).This led to a revolt against the Catholic Church and the emergence of numerous Protestant sects. The horrifyingly bloody warfare between different Christian factions led to a general disillusionment with religion among the public. For details, see "European Transition to Secular Thought" by Zaman (in press).

3. The original message of Christianity had become contaminated with Greek philosophy. When scientific thinking sparked by Islamic Spain started the Enlightenment in Europe, it came into conflict with Church teachings. There was a violent battle between science and Christianity ${ }^{1}$ which was eventually won by science. This also served to discredit religion. 
Secular thinkers rejected the teachings of religion completely, and sought to create a new way to understand the world, without any reference to God. This required a complete rejection of all traditional beliefs, and a re-construction thought on an entirely new basis ${ }^{2}$. For example, Kant thought that "the Enlightenment was mankind's final coming of age, the emancipation of the human consciousness from an immature state of ignorance and error".

\subsection{THE ENLIGHTENMENT PROJECT}

Rejection of God immediately leads to many questions. How did this universe come into existence? What accounts for the harmony and ecological balance that we see in nature? Why does man have a special place in the creation? How should we behave towards each other? How should society be organized? The Enlightenment Project was the name of the attempt to find answers to these questions based on reason alone, without reference to God and the Revelation. It was understood that this might take some time, and indeed, the process of working out secular answers has taken centuries. See Zaman (2009) for a more detailed discussion.

One of the central questions faced by Enlightenment Philosophers was: how was man created? Darwin's theory of evolution became immediately popular because it provided a possible answer to this question. Theories of evolution had been proposed earlier, but these were based on the idea of designed change by a Creator. Darwin's theory was the first which was based purely on chance, and did not require a Creator. It became widespread and widely accepted because it suited the needs of secular thinkers, and not because there was strong empirical evidence in its favor.

In fact, there were many elements of Darwin's theory which were just guesswork. At the time, cellular biology did not exist, and it was widely believed that elementary life forms (like maggots) could arise spontaneously from dust. Genetics was unknown, and Darwin also thought that acquired characteristics could be inherited. It was learned much later that the most elementary life form is a cell. Even the simplest cell is so extremely complex that it is impossible to conceive that it could arise spontaneously from a random combination of elements. Current theories hypothesize that there existed sequences of more elementary life forms that gradually became more and more complex and eventually became cells. Then they conveniently disappeared from the scene, leaving no traces 
behind. No one has a clue as to what these life forms were and how they evolved to create cells. However, once we are committed to denying God, then we must have faith that such a sequence of invisible life forms must have existed and that we will eventually find a "scientific" explanation for the creation of a cell.

The point of this discussion is that scientific theories often have gaps, conflicts with empirical evidence, and other puzzles and contradictions. The process of filling the gaps, resolving conflicts, and solving puzzles is part of the normal process of accumulation of scientific knowledge. Contrary to what is widely believed, acceptance of the theory of evolution was not due to its good fit to empirical evidence; there were other equally good evolutionary theories available. Evolution was a necessary ingredient of a secular world view since it provided an explanation for the creation of man without invoking a Creator. This need was the reason for its acceptance and popularity.

\subsection{THE ATTEMPTTO PROVE THE SUPERIORITY OF SCIENTIFIC KNOWLEDGE}

Logical Positivism is a theory of knowledge. Development of a theory of knowledge became critical in the West following the rejection of Christianity. It was realized that near consensus, and the weight of authority and tradition counts for nothing --- nearly everybody in Europe had believed in Christianity and it still turned out to be wrong. So what kind of knowledge was reliable? The European answer was that we can only trust that which can see and touch. This became the foundation for the theory of logical positivism. Having rejected religion, the Europeans turned Science into their new religion. Science became (and continues to be) a term of reverence. If something is "scientific" that means it is good, true, and reliable. Something which is "unscientific" is bad, irrational, superstitious and unreliable. Just as religion was trusted before, so it became an article of faith among Europeans that science would deliver all truths needed by mankind eventually.

The central question that arose was: how to distinguish between science and non-science? The "philosophy of science" was an attempt to prove the superiority of scientific knowledge over all other types of knowledge. There was a clear cut understanding that science deals with the world we can see and touch, while religion deals with the unseen and the unobservable. The attempt was made to define science by restricting it to observables. But this ran into a 
problem. In religion, we look at the organization and coherence of the world, the in-built moral sense of man, and many other signs (Óyah), and from these we deduce the existence of God. In science also, we look at the falling apples and deduce the presence of the unseen and invisible force of gravity. Similarly, science contains lots of unobservables like atoms, electrostatic charges, and many others. So simple attempts to differentiate between science and religion on the basis of the idea that science deals only with observables failed.

\subsection{BERTRAND RUSSELL'S THEORY OF DESCRIPTIONS:}

In the early twentieth century, an extremely influential article by an extremely influential atheist showed a way to solve the problem. Russell (1910) was concerned with solving a philosophical puzzle which has nothing to do with science or religion on the surface. The problem arises in connection with terms like "unicorns" or "dragons" or "Pegasus" or other mythical creatures. It is obvious that these don't exist. Yet, at the same time, we can tell stories about them and talk about them without any difficulty created by their non-existence. Certain philosophical considerations too complex to discuss here suggest that if we talk about something, it must have some kind of an existence, if not in the real world then at least as a concept. Russell argued that this was not true. We could regard the term "unicorn" as a description of an animal which looks like a horse but has a single horn growing from its head. We make a description but this does not commit us to the existence of anything which has this description.

This essay of Russell led to the birth of logical positivism. The main idea of logical positivism was that every scientific concept that refers to unobservables can be reduced to its observable implications. When we talk about gravity, we are not committed to saying anything about whether or not gravity as a real invisible force exists. Rather, the term gravity is just a shorthand expression for its observable implications. Similarly, atoms, electrons, forces, and all other invisibles are just names (like unicorns or dragons) which describe some collection of observable properties - they do not refer to any real objects which exist in the world. These names serve to organize collections of observations.

\subsection{THE TRIUMPH OF LOGICAL POSITIVISM}

The key idea of logical positivism was that the meaning of a sentence was equivalent to the set of its observable implications. So 
when we talk about (unobservable) gravity, what we really mean is the (observable) implication that the Earth moves around the sun in an elliptical orbit. This provided a perfect solution to the problem of discriminating between science and non-science. Science dealt with theories about this world, and all scientific theories had observable implications, and hence were meaningful. In contrast, statements about God, angels, the hereafter, etc. had no observable implications and hence were meaningless. Note the contrast between the positivist denial of the unseen and the Quranic assertion that it contains guidance for those who believe in the unseen.

Logical Positivism was such a perfect fit to what atheistic and secular scientists had been hoping to find that the philosophy became nearly universally accepted in the Western academia. This influence led to a spread of the core beliefs of logical positivism to the general public as a whole. What is crucial to understand here is that Logical Positivism was not a valid scientific theory. Rather, it was a research program, or a hypothesis about the nature of scientific knowledge. To understand this better, it is useful to go back to the theory of Evolution.

Illustrative Example of Evolution: The idea of evolution is a scientific hypothesis which has many implications and ramifications. There is micro-evolution, which states that within a species, changes occur by the process of evolution, relying on the mechanism of the survival of the fittest ${ }^{3}$. There is macro-evolution, which suggests that one species can change into another; for example birds can evolve from land animals. The evidence for this is indirect and weak. If Darwin's theory regarding macro-evolution was valid, then we would find many "missing links" which would show the gradual evolution of one species into another. However, the fossil record failed to show these missing links ${ }^{4}$, leading to the development of a new theory in 1972 by Gould. Gould argued for "punctuated equilibrium" which says that instead of being a gradual process, evolution takes place in very rapid jumps over a very small period of time, and does not leave a fossil record of the process. This new theory is still under debate and there exist arguments and evidence pro and con. The point of our discussion is that crucial ingredients of the theory of macro-evolution are still under debate and far from proven one hundred and fifty years after the publication of the Origin of the Species by Darwin. Evolution is so universally accepted that attempts by Christians to provide alternative theories in schools have been rejected in US Courts. Despite this universal acceptance, the 
theory remains a hypothesis, with many puzzles, conflicts and contradictions with empirical evidence.

The point of this example was to show that widespread acceptance of a scientific theory does not mean that it has been proven. Even worse, although logical positivism has now been decisively rejected, the theory came to be nearly universally accepted in the early twentieth century. It continues to exercise a powerful influence. Most people find it hard to believe that formulation of the social sciences has been deeply influenced by a theory which is completely wrong. Would not a wrong theory sooner or later be discovered to be wrong and revised? We now turn to an explanation of this phenomenon.

\section{HARMFUL INFLUENCE OF LOGICAL POSITIVISM ON SOCIAL SCIENCE}

As Kuhn (1970) has shown, it is not the rejection of a theory but the emergence of an alternative which leads to its abandonment. Logical Positivism continues to exercise widespread influence because no serious alternative has emerged. In this section, we document the collapse of Logical Positivism, and also trace some of the harmful effects that this wrong philosophy has had on social sciences.

\subsection{FOUNDATIONS OF SOCIAL SCIENCE:}

Logical positivism was a set of conjectures about the nature of scientific theory, and more generally about the nature of human knowledge. Some of the finest minds of the twentieth century struggled to prove these conjectures. However these efforts led to the conclusion that "nearly all of it was false," (Ayer, 2008), one of the leading early exponents of this philosophy. Von Fraasen (1980: 2), a staunch empiricist, writes "Today, however, no one can adhere to any of these philosophical positions to any large extent. Logical positivism, ... even if one is quite charitable ... had a rather spectacular crash." Suppe (1977) wrote a comprehensive epitaph which discusses the many difficulties with logical positivism in detail. To put the matter in a nutshell, science also involves unobservables in an essential way, and these cannot be reduced to descriptions as per Bertrand Russell's prescription.

In a very strange twist in this history of ideas, Logical Positivism did not have much impact on the development of physical sciences. However, it had a profound impact on the 
development of social science in the twentieth century. Logical Positivism led to a nominalist view of the physical sciences terms like "electrons", "gravity" and other invisibles were just names, without any underlying real existence. However, since these served to organize thought, there was no harm if physicists continued to believe in these terms as being real. So physicists, chemists, biologists continued to believe in atoms, molecules, and genes; they were "realists" even though positivists espoused a "nominalist" philosophy of science.

However, the positivist (wrong) description of scientific methodology was extremely influential in shaping social science. Social sciences were struggling for respectability in the early twentieth century. Whereas the physical scientists were secure in their accomplishments, social science was considered an inferior branch of knowledge, with less intellectual content and value. The tension between the two is captured in Snow (2012). Snow (2012) argued that British were left behind because they paid more attention to the humanities, Greek and Latin, whereas Germans and Americans gave more emphasis to the sciences. He argued that in the modern age, thermodynamics was more important than Shakespeare. Similarly, Lord Kelvin argued that you only have knowledge of things which you can measure; qualitative knowledge is substantially inferior (see Rahim and Zaman, 2009, for a discussion and evaluation of this argument). There was a struggle to measure things, and to turn humanities into a science, and thereby make it a respectable branch of knowledge. For example, even in English literature, some people started counting words, word and sentence lengths, and using these as measures and indicators of literary styles.

\subsection{THE BATTLE OF METHODOLOGIES}

It seems clear that human beings are very different from the particles and even from other animals. Can there be a "science" which studies human beings? If so, would it be like the physical sciences? These questions were hotly debated in the early twentieth century. There are many reasons to believe that there cannot be a science which studies human beings. Human beings are not subject to deterministic laws which are the defining feature of science. Someone who has been a sinner all his life can repent and become a saint, and vice versa. Any regression on past data will lead to wrong conclusions about such people. Basically, the past human behavior does not 
determine the future. Many verses of the Quran show that man has been given free choice. For example, Quran (verse 73:19) states that "whoever wants to may choose the pathway to Allah". Further, Quran (verse 90:10) says "We have shown him the two highways (of good and evil)".

If a man is free to choose and his behavior is not predictable by any universal laws of behavior, and not subject to quantification and mathematicization, then how can there be a science about human beings? This issue was a subject of a major intellectual battle (methodenstreit) in the late nineteenth and early twentieth century. On one side was the German Historical School, which placed stress on the freedom of human beings, and the necessity of studying history for understanding human social experience. They rejected the philosophy of material determinism which argues that material circumstances determine the path of history. In contrast, the Austrian school favored deriving logical rules from first principles and claimed that their theories of human behavior based on self-interest were universally valid. Even though the Historical School was right and the Austrian School was wrong, the spirit of the age, as reflected in the philosophy of the logical positivism, led to a complete triumph of the Austrian school. In the rest of the section, we document these assertions. A more detailed discussion is provided in Zaman (2013c).

Logical positivism circumscribed knowledge as being confined to science. Anything that was not science was not knowledge. This favored the Austrian school, since universal laws are scientific. The position of the historical school was dismissed as "un-scientific" which in fact it was. But the point is the human behavior is not governed by universal laws. Suppose that we define an economic law as a universal rule in the economic domain. That means this rule must be equally valid across the continents in India, Africa, USA and Europe. It must be valid across time, working in golden age Baghdad, the Zulu Empire, Medieval Europe, just as well as modern Germany and Japan. The question is: Is there any economic principle which has such universal applicability? The entire edifice of modern economic theory is built on the idea that utility maximization by consumers and profit maximization by producers are such universal principles. Furthermore, in combination, these principles determine the economic laws governing all societies. However, there is now massive empirical evidence that neither of these principles is valid. A general critique of all aspects of microeconomic theory is provided by Lee and Keen (2004). For a guide to the empirical evidence against utility maximization (see Karacuka and Zaman, 2013). Keen 
and Standish (2010) debunk the neoclassical theory of the firm. Saglam and Zaman (2012) show that the theory that prices are determined by equilibrium of supply and demand does not work.

To put the same matter in a different light, consider trade between Pakistan and India. Surely, understanding international trade must take into account the fact the circumstances surrounding the emergence of the countries, the wars that have taken place between the two, and the current political tensions between the two. However, all of these are particular historical facts, and a "scientific" economic theory based on universal laws cannot take them into account. All current economic textbooks of trade consider the theory of trade as taking place between countries $\mathrm{X}$ and $\mathrm{Y}$ without any attention to particular geo-political circumstances of $\mathrm{X}$ and $\mathrm{Y}$. Thus the theory applies equally well (or poorly) to trade between England and France, between Japan and Sudan, and between Bahrain and Qatar. History is ignored by economic theory not because it is irrelevant, but because of the triumph of false doctrine of logical positivism, which says that knowledge is confined to science and scientific laws alone (see Hodgson, 2001, for a detailed account of how the wrong methodology became dominant in economics). A deeper and more general discussion of how mistakes in understanding the methodology of the physical sciences led to mistakes in the foundations of social sciences is provided by Manicas (1987).

\subsection{IS KNOWLEDGE CONFINED TO SCIENTIFIC KNOWLEDGE?}

One of the main claims of the positivists was that all human knowledge is scientific knowledge. Even now, after the collapse of positivism, this continues to be widely believed. One of the reasons for the collapse of positivism was the discovery that there are many other types of human knowledge. The object of this subsection is to establish this claim.

Logical Positivists denied the existence of "synthetic a priori" knowledge. That is knowledge about the real world that is not based on experiences. If children are born with knowledge, then such knowledge cannot be "scientific" because it is not based on observations and logic. Islam asserts the existence of synthetic a priori knowledge. Children are born on Islam; meaning they have inbuilt knowledge of certain kinds. God created all human souls and made us recognize Him (Quran 7: 172). This recognition of our Creator is built into our spiritual natures. Apart from this evidence from Islamic point of view, there is plenty of empirical evidence 
proving the existence of a priori knowledge. Birds are born with inbuilt knowledge of complex migratory patterns and routes. Children are born with knowledge of how to suckle milk. In a more sophisticated study, Noam Chomsky showed that children must have innate knowledge of an underlying universal grammar, in order to be able to pick up languages with the ease that they display; see Pinker (2007) for an exposition. Children do not learn language on the basis of the "scientific" model of knowledge, which requires observations of patterns and derivations of rules based on those linguistic patterns. That would take too long, whereas children learn very fast. This is exactly in accordance with the Quran (55: 1-4) - "We created man, and taught him how to speak" - but not in accordance with logical positivist theory of knowledge.

In addition to linguistic abilities, many other types of knowledge are built into the nature of man. In fact, most of what human beings know is not scientific knowledge. The Quran calls itself a "reminder" - meaning that knowledge of moral behavior is built into the human heart. This is obvious from the widespread consensus on moral behavior across cultures. Similarly, our personal experiences are unique for each person on the planet. Because of their uniqueness, they are not subject to scientific analysis. At the same time, these personal experiences form the basis for our understanding of the world we live in. Any of the skills that we acquire, like driving, cooking, swimming, are personal forms of knowledge which are not "knowledge" according to Positivist conceptions. Yet these types of knowledge form the vast majority of what we know. Quite contrary to what positivists asserted, the vast majority of human knowledge is not based on observations and logic. Unfortunately, the positivist claim continues to be widely believed by economists. With few exceptions, the same principles have been widely accepted by Islamic economists; see Haneef and Furqani (2011) for a comprehensive discussion of methodology in Islamic Economics. Zaman (2013d) and Zaman (2013e) provide additional discussion of how an Islamic methodology for social science must be substantially different from the western approach to the subject.

Logical Positivism is clearly wrong. A long list of reasons for its failure is detailed in a comprehensive epitaph by Suppe (2007). Zaman (2012b) shows how the use of positivist methodology in econometrics has led to many mistaken ideas about the nature of statistical inference. The problem we wish to discuss here is: what is the alternative? About this there is not much consensus in the West. There are two main issues where Islam furnishes us an alternative: 
1. Positivism dismisses the unseen; Islam tells us that the unseen is crucial.

2. According to Positivists, morality is nonsense. Islam tells us that morality is central.

In the next two sections, we will show how incorporating these principles could lead to foundations for a new type of economic theory.

\section{THE IMPORTANCE OF THE UNOBSERVABLES}

The idea that science cannot be based on unobservables is false. Physics, Chemistry, Biology and all other sciences frequently use unobservable concepts to organize the observations. Logical Positivists made the mistake of believing that these unobservables could be eliminated and replaced by observables. This later proved to be false, and the philosophy collapsed. Despite this collapse, positivism exercised a tremendous influence on the development of social science in the twentieth century. Under the influence of logical positivism, behavioral psychologists made the effort to study only the observable behaviors of human beings, without looking at the unobservable internal states. However, this effort failed, and cognitive psychology introduced unobservable internal thought structures to understand human beings. Similarly, economists sought to eliminate unobservable internal preferences - these referred to the internal state of pleasure or happiness felt due to consumption. We now discuss the effects of this positivist methodology on economic theory.

\subsection{REVEALED PREFERENCE THEORY:}

One of the effects of positivist methodology on economics was the theory of revealed preference. Instead studying preference, which is an unobservable feeling in the heart, economists sought to study choices, which are observable. Samuelson sought to construct economic theory based on WARP (Weak Axiom of Revealed Preference) and generalizations. It was eventually proven by Houthakker (1950) that revealed preference theory was mathematically equivalent to utility theory. The Nobel prize given to Samuelson cites his contribution in providing a scientific basis for economics. Samuelson showed that economic theory need not discuss unobservable preferences; it can be based entirely on axioms for the observable choices.

However, exactly as positivism failed to eliminate unobservables from science, so the theory of revealed preference fails to eliminate 
unobservables from economics. Wong (2006) has provided a detailed analysis of the fallacy in the logic of Samuelson. Briefly, it can be explained as follows. Suppose that there are no preferences - no internal feelings of satisfaction or pleasure derived from consumption. Then there is no reason for choices to fulfill any of the axioms. Transitivity holds only because if $a$ is preferred to $b$ and $b$ to $c$ than we can conclude that the consumer derived greater satisfaction from the consumption of $a$ and less from $b$, and even less from $c$. It is this that allows us to conclude that the consumer will prefer $a$ to $c$. If the consumer has no feelings, or if he is completely indifferent to the worldly goods, then he will make choices completely at random. This means that the unobservable preferences are still part of the theory, even though they are not explicitly mentioned.

\subsection{NEEDS AND WANTS}

One of the effects of the positivist methodology was to eliminate the distinction between needs and wants. This was considered to be "unobservable" by economists, and hence eliminated from the theory. Before this shift to positivist methodology, scarcity was not considered to be the fundamental economic problem. As Cooter and Rapaport (1984) show, economics was the study of how material resources can be used to further prosperity and development. The "material welfare" approach took into consideration the fact that providing food to the poor was of greater importance than providing musical entertainment to the rich. However, Robbins (1932) redefined the central problem in the light of the positivist understanding that making such distinctions was subjective and not scientific. He argued that economists should concern themselves with the problem of fulfilling all wants, whether or not they were conducive to welfare. Note the un-scientific normative decision which tells us what economics should be about and what economists should do. As we will discuss later, it is impossible to do social science without normative judgments about what is and is not a worthwhile activity for humans.

For example, Samuelson and Nordhaus (1989: 26) state that economists "must reckon with consumer wants and needs whether they are genuine or contrived." Similarly, Stigler and Becker (1977) make the normative claim that "Tastes are the unchallengeable axioms of a man's behavior." If we focus on fulfilling needs of all human beings, then resources available are sufficient for this purpose; see Zaman (2013d) for documentation of 
this fact. However, as Islam teaches, and everyone recognizes, wants are unlimited. Furthermore, they expand as they are fulfilled - give the man a valley full of gold and he will want a second one. This means that the problem of scarcity cannot be solved by increasing production. As more goods are created, more wants will be created. This means that the economist have set themselves an impossible task - to fulfill all wants. The Islamic point of view provides a radically different analysis of the problem and correspondingly, a radically different solution.

Islam encourages the fulfillment of needs, and discourages the fulfillment of idle desires. Instead of trying to fulfill "insatiable" desires as economists do, it teaches us balance (Quran, 25: 67). Those who, when they spend, are not extravagant and not niggardly, but hold a just (balance) between those (extremes) (Quran, 7: 31) "O Children of Adam! Wear your beautiful apparel at every time and place of prayer: eat and drink: But waste not by excess, for Allah loveth not the wasters."

If we consider the economic problem as one of fulfilling the needs of all human beings, then it can easily be shows that scarcity does not exist. That is, there are enough resources available on the planet to fulfill the basic needs of every human being. The fact that people are hungry, sick, homeless, and facing economic misery is not due to lack of resources to feed, clothe, house and educate them. It is due to the attempt by economists to fulfill idle desires of the top $1 \%$. The Israf and Tabzeer done by rich because they don't not recognize the rights of the poor in their wealth, like Qaroon, is the central economic problem. This Quranic diagnosis is the opposite of that given by Samuelson and his followers. Empirically, Sen (1981) came to the same conclusion where famines do not result from scarcity of food, but from the society failing to acknowledge the entitlements of the hungry and the poor to food. See also Zaman (2010a; 2012c) for the hidden normative aspects of scarcity and the contrast between Islamic and neoclassical views.

\subsection{TRUST AND HONESTY}

Because logical positivism says that science cannot be based on unobservables, many characteristics which are crucial to economic development are ignored by economists. As the influence of positivism has declined, there has been increasing recognition of the importance of these invisible elements. There are many such elements, and a complete discussion would be very lengthy. In "Re-Defining 
Islamic Economics" Zaman (in press) discusses ten fundamental contrasts between an Islamic methodology and conventional methodology based on logical positivism. In this short note, we will concentrate on two well known and recognized characteristics of our

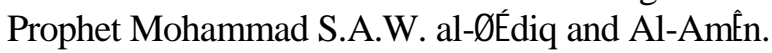

Trust (AmÉnah) has received increasing recognition as a key to economic progress. Levels of trust in a society can vary from high to low. In societies where trust is low, there are high frictional and transaction costs which can substantially slow down economic progress. For example, Zack and Knack (2001) is a seminal study on trust and economic growth. Note the recent date of the paper, which shows how long the blinders of logical positivism prevented economists from noting fundamental factors which contribute to human development. Even now, there has been no recognition of these concepts within the mainstream and none of the conventional micro and macro textbooks incorporate trust into any of the theories being taught to university students. The creation of trust among warring tribes was one of the important factors which led to the rapid rise of Islam. The rapid economic growth of the early Islamic state was due in no small part to the brotherhood created by Islam, which could not have been purchased by all the gold on the planet, as the Quran (8: 62-63) testifies.

Trust requires a foundation in trustworthy behavior, and this is provided by honesty. The development of the characteristics of integrity and honesty among Muslims was crucial to their rapid advance in the world. Today, the poor condition of Muslims all over the world is due to widespread corruption and lack of honesty. Islam puts these characteristics at the center, and Islamic teachings are focused on how to spread the good and to prohibit the evil. Who can doubt that if we were able to create these characteristics among the Muslims, this would cause a rapid turn-around in the worldly conditions facing us? As the Quran (30: 41) tells us, it is evil deeds of men which cause the spread of fasad throughout the world. Learning trust and honesty would require us to focus much more on Islamic teachings, since modern economic textbooks have nothing to say about these matters. Yet, these are far more important for our progress than building industries and acquiring technology. The reason that this is only beginning to be understood in the west is due to the flawed positivist methodology, which led to a systematic disregard of the unobservable factors, and a corresponding exaggeration of importance given to the material and visible factors. 


\section{THE NORMS OF POSITIVE ECONOMICS}

The Logical Positivists claimed that there were only two types of true statements: analytic and synthetic. The analytic statements were true purely due to definitions and logic; for example " $2+2=4$ " is an analytic statement. Synthetic statements were based on observations about nature, such as: All crows are black. Quine (1951) showed that this idea was wrong, i.e.one cannot separate these two types of statements. This was an important factor in the downfall of logical positivism. Extensions of this basic (wrong) idea of the logical positivists led to the fact/value distinction - some statements are purely factual while others express value judgments. Similarly, the positive/normative distinction plays an important role in the methodology of economics. Putnam (2002) has recently shown that these distinctions are also not valid. There are many statements which simultaneously combine facts and value judgments and the two cannot be separated.

Logical positivists put forth the wrong idea that normative and positive sentences can be separated, and that normative statements cannot be part of a scientific theory. This idea continues to be widely believed. It became part of the methodology of economics to state that economics is a "positive" science. It just describes economic reality; it does not make value judgments about it. This was the requirement for being scientific. Unfortunately, it is impossible for any human science to avoid making value judgments. Economics makes a huge number of value judgments, but it is forced to conceal them, since expressing them openly would make it "un-scientific" according to positivist methodology. Zaman (2012c) described how normative assumptions have been built into scarcity, which is the founding concept of modern economics. In this section, we provide some further illustrations to demonstrate the normative nature of current economic theory. Here are some of the value judgments made by economists:

1. Free markets are the best way for organizing the economic functions of production and distribution.

2. Price distortions induced by taxes and tariffs lead to inefficiencies and should be removed.

3. Economists should try to fulfill all wants of consumers, without asking where these wants originate.

4. Competitive markets are good, and monopolies are bad. Labor unions reduce competition in the labor market and therefore are bad.

5. More wealth and production is always better than less.

6. Property rights are more important than basic needs. 
The paper will now explain in detail why all of these propositions of "positive" economics actually incorporate value judgments, and are normative.

\subsection{FREE MARKETS}

The First Fundamental Welfare theorem spells out the conditions under which free markets are efficient. This requires no externalities in production or consumption, full information, no transaction costs, no uncertainties, and a host of other conditions. Nearly all of these conditions are violated in real life. Therefore, when economists sing praises of the free market, it is not a reflection of any economic theory, but merely a normative position. Because Islam also prefers free markets under certain conditions, many Muslim economists have been deceived into believing that this is an Islamic position. In fact, capitalism promotes "unregulated" free markets, whereas Islam regulates markets, subjecting them to many restrictions imposed by the SharẼ̃̃h. Although the difference is subtle, it is extremely important. This is illustrated by the incident in which Umar R.A. insisted that a trader should learn the rules of the Shar㯊h pertaining to trade before opening up a shop. Also, the Quran (68: 27-37) tells us about how Allah TaŃÉÉ destroyed the gardens of the people who wished to avoid giving to the poor. This shows that the spirit of trading in Islam is very different from the capitalist greed which led to collapse of the world financial markets in 2007-8.

Polanyi (2001) has discussed the great transformation that took place in Europe when unregulated markets became a dominant feature of the society. Zaman (2010b) provides a summary and some extensions of these arguments. The disastrous effects of allowing everything to be put on sale have been documented by Schwartz (1994).The commercialization of medicine, education, politics, parenthood, and other aspects of human life normally out of reach of the marketplace has led to disasters on the spiritual and moral fronts. These outcomes illustrate the effects of the normative proposition that markets are the best ways to organize social activities.

\subsection{CONSUMER AND PRODUCER SURPLUS}

In the idealized world of perfectly competitive markets, the only difficulties that arise are due to distorted prices. These lead to the loss of consumer surplus and producer surplus, represented by the triangles in the standard supply and demand diagrams. The World 
Bank (2005) recently published a volume analyzing the growth experience of the 1990's to distill lessons. Analyzing this experience, Rodrik (2006) concludes as follows: One of the insights of Learning from Reform is that the conventional package of reforms was too obsessed with dead weight loss triangles and reaping the efficiency gains from eliminating them, and did not pay enough attention to stimulating the dynamic forces that lie behind the growth process.

The traditional models prioritize price distortions as the main source of inefficiency, leading to policy aimed at eliminating them. There are far more important factors for growth, but these are ignored due to the methodological blinders imposed by logical positivism. For example, corruption and technological inefficiencies account for more than 50\% of power losses in Pakistan. Focus on price reforms wastes energies of the policy makers in areas of minor importance, due to normative biases of conventional economic theory.

\subsection{NEEDS AND WANTS}

Because of the failure to differentiate between needs and wants, economic theory makes the normative judgment that priority is to be judged according to market demand. Accordingly, if the rich demand luxury car imports from Japan, while the poor demand access to medicines and health care, conventional economic theory will give priority to the demand of the rich. This is because the demand will be backed by income power, which will be felt on the market, while the demand of the poor will have no income to back it up. Economic theory tells us that this is the efficient way to make production and consumption decisions. That this is a normative decision is not made clear in the conventional textbooks. This point, which is fundamental, is discussed in greater detail in Zaman (2010a; 2012c).

In section 3.2 we have documented agreement among economists that we should be concerned with fulfilling all wants, without questioning their origin. Obviously this is a normative judgment, and furthermore, this norm is directly in conflict with Islamic norms. For example, the Quran states that: who could be more astray than he who follows [but] his own likes and dislikes without any guidance from God? (28: 50).

Unconstrained fulfillment of desires is a valid goal only for those who have no belief in the hereafter. Furthermore, it is a normative choice of a particular lifestyle (pursuit of luxury), and not the objective rational decision as claimed by economic theory. 


\subsection{MONOPOLIES AND COMPETITION}

The idea that competition is the best way to organize markets is a normative preference based on certain false assumptions about human behavior and motivations. Psychological studies show that babies have empathy, and feel both the joy and suffering of others. Also, they are social, and try to help others in distress. While man is born to be cooperative and generous, on the nature of Islam, he can be trained away from these natural tendencies. Social norms are of utmost importance; these are created by education. The Quran (3: 103) shows that people who were constantly fighting each other learned to be brothers in Islam. That means that if we work together to shape social norms, we can change the attitudes of people.

Studies of why people do business, as well as why people work, show that money is not a major motivational factor. Different people strive for different ends. Social approval, provision of service, challenge, intellectual curiosity, and other motives provide far stronger incentives for work. Pink (2010) has shown that increasing money wage can increase stress which actually lead to declines in productivity for intellectually demanding types of work.

If society trains children to cooperate and to enjoy providing service and help, economic structures of the society can be very different from the competitive markets we see around us. Historically, in Islamic societies, many productive activities were carried out by guilds, who took responsibility of providing certain types of service to society. Islam was spread beyond the Islamic empire by traders, whose scrupulous adherence to Islamic principles and cooperative spirit inspired others to follow them.

Monopolies created with a spirit of service are not harmful; it is only when they seek to profit at the expense of consumers that their power needs to be curbed. Similarly, competition does not promote survival of the fittest. Empirical studies show that firms frequently use unfair means to drive out efficient competitors, so that society is harmed by competition. Cooperation, loyalty, spirit of service are much better matched to natural human motivations, and provide much better results than the law of the jungle.

\subsection{MORE WEALTH IS ALWAYS BETTER}

Economic theory assumes that consumers maximize utility, which is insatiable. So more wealth is always better for the consumer. This is supposed to be a positive fact, not a value judgment. Islam tells us 
that this is not true. The example of QÉrËn is clear, but the same message is re-inforced in many different ways in the Quran. For example, in Surah Al-Fajr (89:14), it is stated that "When Allah TaÑ́la tests a man by giving him honor and wealth, he says that my Lord has honored me." That is, wealth is a trial, and not a sign of the pleasure of Allah. Similarly, it is written (QurQ̀n 17:83) that when man is given excessive wealth, he becomes rebellious. Thus extra wealth is not good for man necessarily. Similarly, it is written (Quran 43: 33) that Allah TaN̈́⿴囗十 would have made the houses of the unbelievers out of gold and silver, but that this would have been too severe a trial for the Muslims. So again the implication is that accumulation of gold and silver is not desirable. Elsewhere (Quran 87: 16-17), it is written that people love the things of this world, but what Allah TaÑ́⿴囗十 has for them in the Ókhirah is much better.

The times of our Prophet S.A.W. were the Khayr al-QurËn, the best of times. However, the Muslims did not have a lot of wealth at that time. In later periods the Muslims acquired a lot of wealth due to conquests. However, these times were less good. It is clear the wealth is not a measure of progress and development, contrary to classical economic theory. Rather, this is a normative judgment on part of economists. This judgment was forced on the economists by the methodology of logical positivism, which insisted that science must be based on measurable criteria. Wealth can be measured, while happiness or internal satisfaction cannot be. The main issue is how to satisfy people, to make them contented and happy, by the use of materials. However, positivism forces us to not look at the internal feeling of satisfaction generated by wealth. After the downfall of positivism, research initiated by Richard Easterlin began to look at the relation between wealth and happiness. His research led to a surprising conclusion widely known today as the "Easterlin Paradox." This states that wealth creates short run happiness, but has no effect on happiness in the long run. This shows how pursuit of wealth prescribed by economists as the solution to all problems is an illusion. For details and additional references, see Zaman (2013d).

\subsection{PARETO PRINCIPLE AND PRIVATE PROPERTY}

Consider two human rights which are widely respected in societies all over the world:

1. All humans have a right to minimum level of wealth required for survival. 
2. All humans have a right to their private property, which cannot be forcibly taken away from them.

There are many situations where these two rights are in conflict. For example, about 25,000 people die daily due to causes related to malnutrition and hunger. At the same time, the wealthiest 500 people have aggregate assets more than the poorest billion people on the planet. The question is: Is the right to property of the rich more important than the right to food of the hungry?

Economists utilize the Pareto Principle to make this decision. According to this principle, if we take resources from the rich and give them to the poor, this is a value judgment which requires interpersonal utility comparisons. Therefore, it is not scientific. Leaving the property in the hands of the rich does not require value judgments, and is therefore scientific.

It is not realized that one must make a value judgment in this situation. Not taking wealth from the rich is a value judgment that property rights are more important than right to life. Taking wealth from the rich to feed the poor is a value judgment that the right to life is more important. Since logical positivism says that normative judgments are not scientific, the economists are forced to argue that their value judgment that the right to property is more important than the right to life (based on the Pareto Principle) is not a normative statement but a positive statement. This is obviously false. Furthermore, the Quran (70:24-25) supports the opposite normative statement. It states that the poor have a known right in the wealth of the rich. In case of desperate need of the poor, property of the wealthy may forcibly be taken from them to provide for the poor.

\section{FOUNDATIONS OF AN ISLAMIC ALTERNATIVE}

There are two major flaws (and many minor ones) in the philosophy of logical positivism:

1. Anything which cannot be observed cannot be a part of a scientific theory.

2. Normative statements cannot be part of science.

Both of these wrong ideas were accepted as valid for most of the twentieth century. These were incorporated into the foundations of economic theory. It was discovered later that both of these positivist ideas are wrong. In this concluding section, we recapitulate and summarize the impact of these errors, and then we discuss how an Islamic alternative would avoid them. 


\subsection{ERRORS OF POSITIVISM}

Science uses unobservables: Science utilizes a lot of unobservables in an essential way. Gravity, electrical charges, many different particles and many different properties are all unobservable. The Positivists thought that these properties and particles could be replaced by their observable implications. However, the attempts to do this failed.

Science requires normative principles: Positivists thought that with enough facts, there will be no need of opinion. The facts will automatically lead us to the right theory. However, it has been discovered that "under-determination" is most common. There are many theories which will fit the same set of facts; see Rashid (2009) for an illuminating discussion. When a variety of theories fit all available observations, choice among them must be made on other grounds. Kuhn (1970, p. 4) writes that "an apparently arbitrary element, compounded of personal and historical accident, is always a formative ingredient of the beliefs espoused by a given scientific community at a given time." Since there is always a multiplicity of theories which fit a given collection of facts, one must select a particular theory on other (subjective) ground. Putnam (2002) shows that the selection of scientific theories involves aesthetic judgments about simplicity, elegance and power. These are values, though often not recognized as such. Copernican theory was favored over the Ptolemaic system, even though it was less empirically accurate, primarily because it was substantially simpler and more elegant. Similarly, the currently popular string theory in physics is being explored because of its elegance, even though there is not a shred of empirical evidence in its favor. Thus values are involved in the selection of scientific theories.

\subsection{FINDING SUITABLE ALTERNATIVES}

Once we reject logical positivism, it becomes necessary to consider which unobservables we will consider as the basis for a new theory. It also becomes necessary to consider what will be the normative basis for a new theory. Secular thinkers have started work in both areas but they are seriously handicapped by the secular mindset. It is here that Islam offers us unique advantages which are not available to secular thinkers.

We first note that Islam provides us with a dramatically successful development model. At the time the prophet Mohammad 
S.A.W. came, the Arabs were the most backwards people on the planet. Other nations like Egyptians, Romans, Persians and Chinese had advanced cultures with literature, philosophy, sciences and technologies which were very far from the reach of the primitive Arab tribes. Yet the message of Islam took them to global dominance within a short period of thirty years. It is surprising that instead of studying this model, Muslim economists are studying Rostow's stages of development. Rostow's model is based on the British Empire's gradual climb to global dominance over three centuries and suggests that we should follow the same pattern and strategies. Surely we should prefer the prophetic model of thirty years over the British model of three hundred years.

Many economists who have grappled seriously with development have come to the conclusion that the key to development is the human being. Development does not occur by lowering tariffs, having suitable macroeconomic policies, striving for high ICOR's (Incremental Capital-Output Ratio) and savings rates, filling the two gaps, or via a big push. Rather, we must focus on human development. For example, after practical experience with failure of conventional economic policies formulated by the Harvard group, Mahbubul-Haq came to the conclusion that: "After decades of development, we are rediscovering the obvious. People are both the means and the ends of development." Similarly, after espousing "institutional economics" for a long time, Rodrik recanted, noting that institutions are composed of people after all. Martha Nussbaum and Amartya Sen have argued that development is mainly about development of human capabilities.

While the development experience, and failures of conventional theories has led these thinkers to focus on human beings, they have no answer to the question of which capabilities should be developed. This is because secular thought does not allow us to prioritize human capabilities. In an earlier part, I suggested that we focus on Trust and Honesty, as it is clear that these characteristics (Al-ØEdiq and AlAm $\hat{\mathbf{E}}$ ) are prized by Allah. Furthermore, the literature on trust and on governance, shows that these play a very important role in economic development. However, this should be taken as an initial and preliminary suggestion. There are a large number of other characteristics which are mentioned as important in the source writings of Islam. As Zaman and Asutay (2009) have argued, Islamic development must go beyond theoretical economics, and the logic of fiqh. It requires vision, will and leadership, as demonstrated by our Prophet Mohammad S.A.W. who changed an entire culture from the 
jÉhiliyyah to Islamic. Thus Islamic teachings provide the essentials required for transforming individuals and societies in desired directions. We need to study these and utilize them to create change, rather than getting advice from Harvard trained foreign experts 5 . Islam provides us with crystal clear guidance on the invisible qualities that we need to focus on; it has complete guidance for us until the day of Judgment (Quran 5: 3).

The second pillar of positivism is the denial of scientific status to normative theories. As we have seen, this is not possible in economics. All economic theories must incorporate normative judgments; see Zaman (2012c). The normative judgments which are part of conventional economics are in conflict with Islamic value judgments. Greed and competitive profit seeking have been rejected by many scholars, who have seen the bad effects of these principles in capitalist economies. However, the secular scholars have no answer to the question of what are the right normative principles to use. This is because there is no basis for morality in a secular worldview. Here again Islam provides us with complete guidance. The teachings of the Quran which relate to economic affairs are vast, and have been covered in many books. Here we only mention one principle, as an initial and tentative beginning for Islamic Economics. This is the principle of spending for the sake of Allah.

The spending of excess wealth for the sake of Allah has received tremendous emphasis in Quran and Hadt̂th. An extremely popular book entitled Fal É(̇) al-Øadaqah, lists these Quranic Óýt and AÍ Éd̂th and explains them in detail over 800 pages entirely devoted to persuading the reader to spend for the sake of Allah. This is dramatically opposed to the capitalist view, where excess wealth should be saved and invested. As many leading economists have noted, this capitalist tendency leads to a massive concentration of wealth at the top. A few people own most of the wealth, while the vast majority (99\%) have very little. This inequality creates huge social problems, as demonstrated by Stiglitz (2012). This is directly against Islamic teachings, which emphasize the circulation of wealth, the feeding of the poor, and spending for the sake of the love of Allah. Following Islamic teachings would lead to substantial improvements in the conditions of the poor, increase in equality and justice, circulation of wealth, and reductions in exploitations of the poor. The early generation of Islamic economists asserted confidently that these would be results of a change to an Islamic economic system. The second generation lost the way, because they got trapped by sophisticated and complex Western economic 
theories. To progress, we must reject these theories, and come back to the simplicity of Islam.

${ }^{1}$ The most famous example is that of Galileo who was forced to recant the heliocentric theory. But Bruno was burnt at the stake, and many other cases of conflicts occurred.

${ }^{2}$ David Hume asked that: "Can I be sure that in leaving all established opinions I am following the truth?" In general, Enlightenment Philosophers thought that they were creating a new stage in evolution of human beings to a higher and more rational form.

${ }^{3}$ Darwin's original theory about how this took place assumed that acquired characteristics of fitness could be inherited; Mendel and genetic theories cameafterword. The mechanism by which micro-evolution takes place is now hypothesized to be mutations, though there are several unresolved puzzles associated with this idea.

${ }^{4}$ Darwin himself was shaken by the absence of the missing links necessary for his theory. He hypothesized that more extensive search would eventually turn up fossils which would support him.

${ }^{5}$ These experts have wreaked havoc all over the world. For example, advice given by Yale trained Sachs led to a $50 \%$ fall in productive output of Russia, and the emergence of widespread poverty and hunger. 


\section{REFERENCES}

Ayer, A. J. (2008). Interview with Brian Magee. http://www.youtube.com/watch?v=4cnRJGs08hE.

Cooter, R. and P. Rappoport "Were the Ordinalists Wrong about Welfare Economics?" Journal of Economic Literature 22, no. 2 (1984): 507-30.

Haneef, M.A. and H. Furqani. "Methodology Of Islamic Economics: Overview of Present State And Future Direction" International Journal of Economics, Management \& Accounting 19, no. 1 (2011): 1-26

Hodgson, G. How Economics Forgot History: The Problem of Specificity in Social Science. New York: Routledge, 2001.

Houthakker, Hendrik S. "Revealed preference and the utility function."Economica 17, no. 66 (1950): 159-174.

Karacuka, M. and A. Zaman. "The Empirical Evidence against Utility Theory." International Journal for Pluralism in Economics Education 14, no. 1 (In press).

Keen, S. and R. Standish. "Debunking the Theory of the Firm Chronology", Real World Economics Review 53, (26 June 2010): 56-94. http://www.paecon.net/PAEReview/issue53/KeenStandish53.pd.

Kuhn, T.S. The Structure of Scientific Revolutions. Chicago University of Chicago, 1970.

Lee, F.S. and S. Keen. "The Incoherent Emperor: A Heterodox Critique of Neoclassical Microeconomic Theory." Review of Social Economy 62, no. 2 (2004): 169-99.

Manicas, P.T.A History and Philosophy of the Social Sciences. Oxford: Basil Blackwell, 1987.

Pink, D.H. Drive: The Surprising Truth about What Motivates Us. Edinburgh: Canongate, 2010.

Pinker, S. The Language Instinct: How the Mind Creates Language. New York: Harper Perennial Modern Classics, 2007.

Polanyi, K. The Great Transformation: The Political and Economic Origins of Our Time. Boston: Beacon Press, 2001

Putnam, H. The Collapse of the Fact/Value Distinction and Other Essays. Cambridge: Harvard University Press, 2002.

Quine, W.V. "Main Trends in Recent Philosophy: Two Dogmas of Empiricism." The Philosophical Review (1951): 20-43.

Rahim, F. and A. Zaman. "Corruption: Measuring the Unmeasurable." Humanomics 25, no. 2 (2009): 117-26. 
Rashid, S. 'Underdetermination, Multiplicity and Mathematical Logic.” 2009, http://philsci-archive.pitt.edu/archive/00004905/.

Robbins, Lionel An Essay on the Nature and Significance of Economic Science. NY: Macmillan, 1932.

Rodrik, D. "Goodbye Washington Consensus, Hello Washington Confusion? A Review of the World Bank's Economic Growth in the 1990s: Learning from a Decade of Reform." Journal of Economic Literature 44, no. 4 (2006): 973-87.

Russell, B. "Knowledge by Acquaintance and Knowledge by Description."Proceedings of the Aristotelian Society 11 Oxford: Blackwell Publishing, 1910.

Saglam, I. and A. Zaman "The Conflict between General Equilibrium and the Marshallian Cross." ERF Working Paper no. 1219 , Koc University, 2012 ,

http://eaf.ku.edu.tr/en/workingpapers.

Samuelson, P. and W.D. Nordhaus. Economics (16 ${ }^{\text {th }}$ ed.). NY: McGraw Hill, 1989.

Schwartz, B. The Costs Of Living: How Market Freedom Erodes The Best Things In Life. NY: WW Norton \& Co, 1994.

Sen, A. Poverty and Famine. Oxford, UK: Clarendon Press, 1981.

Snow, C.P. The Two Cultures. Cambridge UK: Cambridge University Press, 2012.

Stigler, G.J., and G.S. Becker."De gustibus non est disputandum." The American Economic Review 67, no. 2 (1977): 76-90.

Stiglitz, J.E. The Price of Inequality: How Today's Divided Society Endangers Our Future. NY: WW Norton, 2012.

Suppe, F. The Structure of Scientific Theories (2 ${ }^{\text {nd }}$ ed.) Chicago: Univ of Illinois Press 1997.

Tawney, R. H. Religion and the Rise of Capitalism. New York: Harcourt, Brace and Co., 1926.

Tuchman, B.W. The March of Folly: From Troy to Vietnam. NY: Ballantine Books, 1985.

van Fraassen, B.C. The Scientific Image. New York: Oxford University Press, 1980.

Wong, S. Foundations of Paul Samuelson's Revealed Preference Theory. NY: Routledge, 2006.

World Bank. Economic Growth in the 1990s: Learning from a Decade of Reform. Washington, D.C.: World Bank, 2005.

Zack, P. and S. Knack, "Trust and Growth." Economic Journal, 111(2001), 295-321. 
Zaman, A. "Origins of Western Social Science." Journal of Islamic

Economics, Banking and Finance 5, no. 2 (2009): 9-22 "Scarcity: East and West," Journal of Islamic Economics,

Banking and Finance 6, no. 1, (2010a): 87-104

"The Rise and Fall of Market Economies." Review of

Islamic Economics 14, no. 2 (2010b): 123-155

."An Islamic Critique of Neoclassical Economics," Pakistan

Business Review, April (2012a): 9-42

"Methodological Mistakes and Econometric

Consequences." International Econometric Review 4, iss. 2 (2012b): 99-122.

."The Normative Foundations of Scarcity," Real-World Economics Review 61 (2012c): 22-39.

"Re-Defining Islamic Economics." In Islamic Economics:

Basic Concepts, New Thinking and Future Directions, Cambridge, UK: Cambridge Scholars Publishing (in press).

. "Deification of Science and its Disastrous Consequences,"

SSRN Working Paper 2260052 http://ssrn.com/abstract=2260052 (April 2013).

. "Directions for Muslim Scholars in Social Sciences."

Proceedings of Third Arab-Turkish Congress of Social Sciences. Istanbul (2013).

. "Islam versus Economics." In Oxford University Handbook on Islam and the Economy, edited by Kabir Hassan and Mervyn Lewis. Oxford: Oxford University Press, (2013d): Chapter 3.

. "An Islamic Approach to Humanities." Paper presented at the

$2^{\text {nd }}$ International Conference on Islamic Humanities, Iran, 16-20

November 2013.

., "European Transition to Secular Thought: Lessons for Muslims." Insights, Da'wah Academy, IIUI, Islamabad, (In Press).

and M. Asutay, "Divergence between Aspirations And Realities of Islamic Economics: A Political Economy Approach to Bridging the Divide.'IIUM Journal of Economics and Management 17, no. 1 (2009): 73-96. 